\title{
Helicobacter pylori CagA protein activates Akt and attenuates chemotherapeutics-induced apoptosis in gastric cancer cells
}

\author{
Keng-Hsueh Lan ${ }^{1}$, Wei-Ping Lee ${ }^{2,7}$, Yu-Shan Wang ${ }^{3}$, Shi-Xian Liao ${ }^{4}$ and Keng-Hsin \\ $\operatorname{Lan}^{4,5,6}$ \\ ${ }^{1}$ Division of Radiation Oncology, Department of Oncology, National Taiwan University Hospital National Taiwan University \\ Cancer Center, Taipei, Taiwan \\ ${ }^{2}$ Department of Medical Research, Taipei Veterans General Hospital, Taipei, Taiwan \\ ${ }^{3}$ Institute of Molecular Medicine and Bioengineering, National Chiao Tung University, Hsinchu, Taiwan \\ ${ }^{4}$ Division of Gastroenterology and Hepatology, Department of Medicine, Taipei Veterans General Hospital, Taipei, Taiwan \\ ${ }^{5}$ Department of Medicine, School of Medicine, National Yang-Ming University, Taipei, Taiwan \\ ${ }^{6}$ Department and Institute of Pharmacology, National Yang-Ming University, Taipei, Taiwan \\ ${ }^{7}$ Department and Institute of Biochemistry, National Yang-Ming University, Taipei, Taiwan \\ Correspondence to: Keng-Hsin Lan, email: khlan@vghtpe.gov.tw
}

Keywords: Helicobacter pylori; CagA; Akt; chemotherapeutics

Received: July 21, $2017 \quad$ Accepted: November 13, $2017 \quad$ Published: December 09, 2017

Copyright: Lan et al. This is an open-access article distributed under the terms of the Creative Commons Attribution License 3.0 (CC BY 3.0), which permits unrestricted use, distribution, and reproduction in any medium, provided the original author and source are credited.

\section{ABSTRACT}

Infection with cagA-positive Helicobacter pylori is associated with a higher risk of gastric cancer. The cagA gene product, CagA, is translocated into gastric epithelial cells and perturbs host cellular biological functions. Etoposide, a topoisomerase II inhibitor widely used to couple DNA damage to apoptosis, is a common cytotoxic agent used for advanced gastric cancer. We investigate the effect of CagA on etoposideinduced apoptosis in gastric cancer cells to elucidate whether CagA play a role in gastric carcinogenesis via impairing DNA damage-dependent apoptosis. AGS cell lines stably expressing CagA isolated from $H$. pylori 26695 strain were established. In the presence of etoposide, viability of parental AGS cells was decreased in a time-and dose-dependent manner, whereas CagA-expressing AGS cells were less susceptible to etoposide induced cell-killing effect. Suppression of etoposide-induced apoptosis was shown in CagA-expressing but not in parental AGS cells by DNA fragmentation, cell cycle, and annexin-V assays. This inhibitory effect of etoposide-induced apoptosis conferred by CagA was also demonstrated in SCM1 and MKN45 gastric cancer cell lines, with two additional chemotherapeutics, 5-FU and cisplatin. The effect of Akt activation on inhibition of etoposide-induced cytotoxicity by CagA was also evaluated. CagA expression and etoposide administration activate Akt in a dose-dependent manner. Enhancement of etoposide cytotoxicity by a PI-3-kinase inhibitor, LY294002, was evident in parental but was attenuated in CagA-expressing AGS cells. CagA may activate Akt, either in the absence or presence of etoposide, potentially contributing to gastric carcinogenesis associated with $H$. pylori infection and therapeutic resistance by impairing DNA damage-dependent apoptosis. 


\section{INTRODUCTION}

Helicobacter pylori (H. pylori) is a Gram-negative bacterium infecting human gastric mucosa with worldwide prevalence. This bacterium contributes to the pathogenesis of chronic gastritis, peptic ulcers, gastric adenocarcinomas, and gastric mucosa-associated lymphoid tissue lymphomas [1]. Several studies have shown that cytokine production, apoptosis, and cellular proliferation are induced in gastric mucosa infected with $H$. pylori, and that these cellular responses play a crucial role in gastric inflammation, atrophy, hyperplasia, and carcinogenesis [2-6]. Increasing evidence suggests that $H$. pylori is causally linked to gastric cancer. A report summarized all available case-control studies and concluded that the relative risk for the development of gastric cancer was 3.8-fold higher in patients with $H$. pylori infection compared to those without infection. Additionally, this risk increased to 8.7 -fold 15 years after the diagnosis of $H$. pylori infection [7]. In a meta-analysis of 42 cohort and case-control studies, Eslick et al. reported an association between $H$. pylori infection and gastric cancer with the overall odds ratio of 2.0 (95\% CI 1.7-2.5) [8]. In animal studies, several groups have shown the development of adenocarcinoma in the antral or pyloric region of Mongolian gerbils infected with H. pylori [9-11]. Given the causal role of $H$. pylori infection in the development of gastric carcinoma, the World Health Organization has classified $H$. pylori as a class I carcinogen.

Several factors have been proposed to be possible virulence determinants of $H$. pylori, including the $\operatorname{cag} A$ gene, a marker gene for the cag pathogenicity island [12]. Among various $H$. pylori strains, cagA-positive $H$. pylori strains are more virulent than $\operatorname{cag} A$-negative strains and are associated with gastric carcinoma. CagA is believed to evoke an increased inflammatory response through epithelial cell release of interleukin 8, leading to active inflammation [13]. The presence of this gene has been strongly linked to gastric mucosal cell damage [14]. After attachment of $\mathrm{cag} A^{+} H$. pylori to gastric epithelial cells, CagA is directly injected into the cells via the bacterial type IV secretion system and undergoes tyrosine phosphorylation on specific EPIYA sequence repeats by Src family tyrosine kinases in the host cells [15-18]. The phosphorylated CagA specifically binds Src homology 2 domain-containing protein tyrosine phosphatase (SHP-2), activates the phosphatase activity, thereby inducing morphological transformation of cells [19]. These steps trigger downstream events leading to $\mathrm{H}$. pylori-associated apoptosis and cellular proliferation. An international survey identified a strong association between CagA status and pepsinogen levels that are markers of gastric atrophy [20].

Etoposide induces DNA cleavage and prevents DNA strand reconnection, leading to DNA strand breaks. Cancer cells are more dependent on topoisomerase than healthy cells due to the higher proliferation rate. Thus, etoposide causes the errors in DNA synthesis and promotes apoptosis of cancer cells [21]. Etoposide is an important cancer chemotherapeutic agent with clinical activity against a broad range of human malignancies [22], including gastric cancer. Etoposide has been shown to activate phosphatidylinositol 3-kinase/Akt signaling pathway [23], which induces resistance of gastric cancer cells to chemotherapeutic agents [24, 25]. Administration of a small molecule inhibitor of the phosphatidylinositol 3-kinase (PI3K), LY294002, greatly potentiated apoptosis caused by etoposide [26].

CagA has been shown to promote gastric carcinogenesis directly by affecting host cell signaling pathways, or indirectly by inducing tissue damage and inflammation [27]. The purpose of this study is to evaluate whether the CagA of $H$. pylori is implicated in resistance of gastric cancer cells to etoposide-induced apoptosis and to explore the possible mechanism.

\section{RESULTS}

\section{CagA-expressing AGS cells are less susceptible to etoposide-induced cytotoxicity}

Specific expression of CagA was noted in transiently transfected AGS cells and two stable transfectants (Figure 1A). To determine the effect of CagA expression on etoposide-induced cytotoxicity, AGS/FLAG and AGS/ FLAG-CagA cells were treated with various concentrations of etoposide $(0-300 \mu \mathrm{M})$ for 24 to $48 \mathrm{~h}$. The AGS/FLAG cells were susceptible to etoposide in a dose- and timedependent manners while the AGS/FLAG-CagA cells demonstrated attenuated cytotoxicity (Figure 1B and 1C). While the concentration of etoposide causing $50 \%$ of the cell death $\left(\mathrm{IC}_{50}\right)$ after $48 \mathrm{~h}$ of treatment is $21 \mu \mathrm{M}$ for AGS/ FLAG cells, the $\mathrm{IC}_{50}$ was increased to $150 \mu \mathrm{M}$ for AGS/ FLAG-CagA cells (Figure 1D). The difference was even more evident after drug exposure for $24 \mathrm{~h}$, with the $\mathrm{IC}_{50}$ being 14 folds higher in CagA-expressing than parental AGS cells (1 mM vs $70 \mu \mathrm{M})$ (Figure 1D).

\section{CagA prevents etoposide-induced DNA fragmentation and PARP cleavage}

Degradation of chromosomal DNA into oligonucleosomal fragments represented by multiples of 180-200 bp DNA on agarose gel electrophoresis is one of the hallmarks of apoptosis. DNA ladder formation was evident in AGS/FLAG cells after etoposide treatment for $48 \mathrm{~h}$ (Figure 2A; lane 2) but not in untreated AGS/FLAG cells (lane 1) or AGS/FLAG-CagA cells untreated (lane 3) or treated (lane 4) with etoposide. These results indicate that etoposide induced apoptotic cell death in AGS cells, whereas CagA expression suppresses the apoptotic effect of etoposide. 
PARP is a nuclear DNA-binding protein that detects and binds to DNA strand breaks. Full-length PARP is a $116 \mathrm{KDa}$ stress response protein that repairs damaged DNA. Proteolytic cleavage of PARP into $89 \mathrm{KDa}$ and

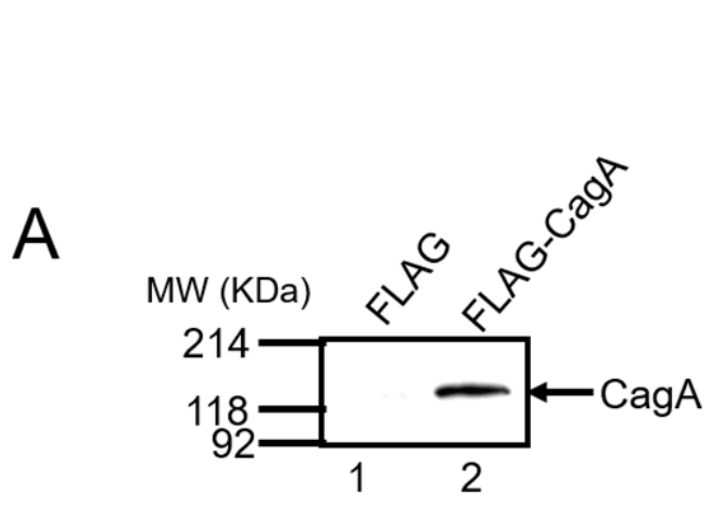

B

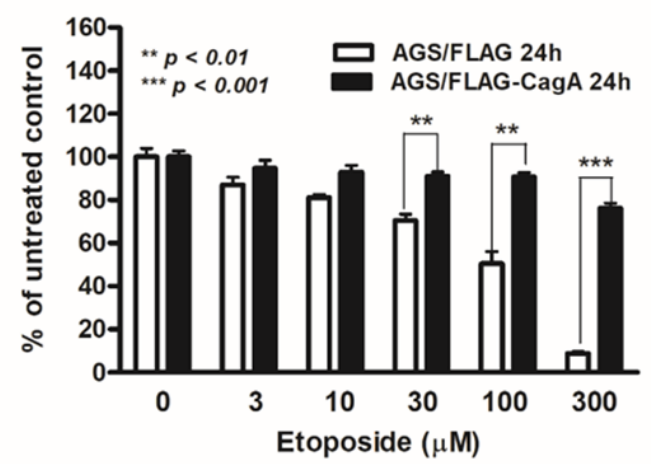

$24 \mathrm{KDa}$ fragments by caspases is a well-established hallmark and an early indicator of apoptosis. To evaluate the cytoprotective actions of CagA, the levels of cleaved PARP in parental or CagA-expressing AGS cells were

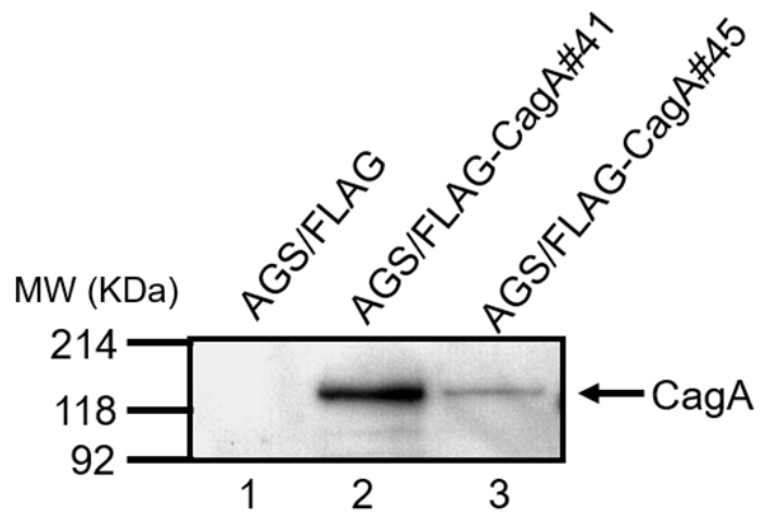

C
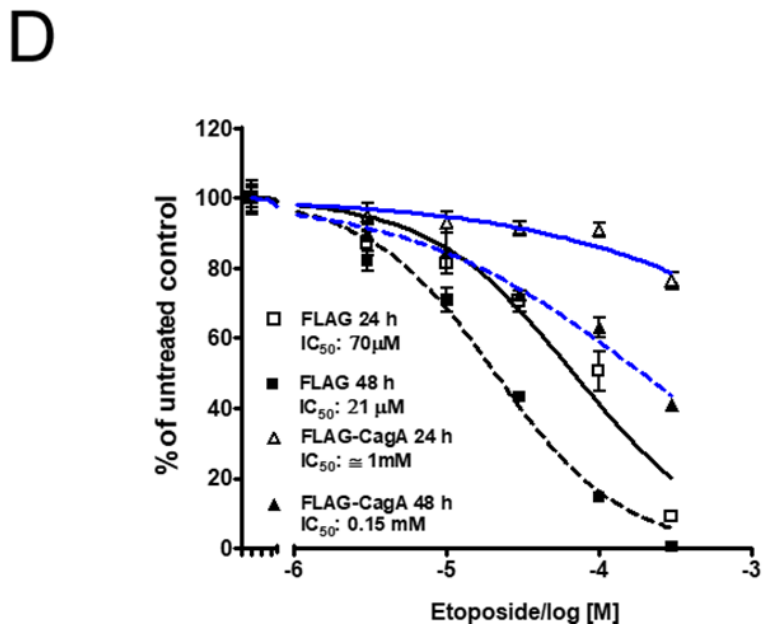

Figure 1: Effect of the CagA on cell viability after etoposide treatment. (A) Specific CagA expression with the expected molecular weight $128 \mathrm{KDa}$ was noted in AGS cells transiently transfected p3XFLAG-CagA but not in p3XFLAG control. CagA expression was also noted in two CagA-expressing AGS stable transfectants (right panel). (B and C) Control or stable CagA-expressing AGS cells (7 $\times 10^{4} /$ well) were treated with etoposide at the concentrations indicated. After being cultured for $24 \mathrm{~h}(\mathrm{~B})$ or $48 \mathrm{~h}(\mathrm{C})$, cells were subjected to MTT assay. Results are presented as mean $\pm \mathrm{SEM}$ of three independent determinations. (D) Inhibition curves of the IC ${ }_{50}$ of $A G S / F L A G$ and AGS/FLAG-CagA cells when exposed to etoposide for $24 \mathrm{~h}$ and $48 \mathrm{~h}$ were plotted using GraphPad Prism software. 
examined following treatment of various concentrations of etoposide $(0-160 \mu \mathrm{M})$ for $6 \mathrm{~h}$. PAPR cleavage was evident by etoposide treatment in AGS/FLAG (Figure 2B; left panel) but the effect was attenuated in AGS/FLAGCagA cells (right panel).

\section{Etoposide-induced apoptosis was blocked in stable CagA-expressing AGS cells}

To further evaluate the impact of CagA expression upon etoposide-induced apoptosis, two AGS cell lines stably transfected with CagA (AGS/FLAG-CagA \#41, and \#45) were treated with $50 \mu \mathrm{M}$ etoposide for the time indicated. Cells were stained with propidium iodide, and apoptosis was scored by the appearance of a sub- $\mathrm{G}_{1}$ peak, a characteristic of apoptosis. Before the treatment of etoposide, there was no significant difference in the sub- $\mathrm{G}_{1}$ peaks of the control AGS/FLAG and AGS/p3XFLAGCagA cells. While $7.24 \%$ and $12.99 \%$ of apoptotic cells appeared in AGS/FLAG cells after 24 and $48 \mathrm{~h}$ treatments, respectively (Figure $2 \mathrm{C}$; left panel), both AGS/p3XFLAGCagA stable cells showed less than $3 \%$ of apoptotic cells at the corresponding time points (middle and right panel).

\section{CagA-expressing gastric cancer cell lines attenuate apoptosis induced by chemotherapy drugs}

To further confirm the apoptosis blockage phenomenon induced by CagA on gastric cancer cells, two additional gastric cancer cell lines and another two chemotherapeutic agents, 5-FU and cisplatin, were used to evaluate the phenomenon. CagA transfected AGS, SCM1 and MKN45 cell lines were treated with etoposide, 5-FU and cisplatin for the $24 \mathrm{~h}$ and analyzed by annexin-V assay. As shown in Figure 3A, apoptotic cell death was attenuated when CagA-expressing cells were treated with etoposide, 5-FU or cisplatin from $47.05 \%$ of vector control to $18.69 \%$ in etoposide, from $29.4 \%$ of vector control to $11.77 \%$ in $5-\mathrm{FU}$ and from $32.5 \%$ to $20.13 \%$ in cisplatin. The expression of CagA weakened the execution stages of apoptosis in another gastric cancer cell line (SCM1), also treated with etoposide, 5-FU or cisplatin (Figure 3B). Vector control of SCM1 showed $53.82 \%, 44.30 \%$ and $58.03 \%$ of apoptosis on treatment of etoposide, 5-FU and cisplatin, respectively, whereas CagA-expressing SCM1 cells attenuated apoptosis to $29.23 \%, 25.51 \%$ and $48.53 \%$ (Figure $3 \mathrm{~B}$ ). To validate the observations that the expression of CagA affects cell sensitivity to the studied drugs, we assessed the outcome of etoposide, 5-FU and cisplatin on another gastric cell line, MKN45. As shown in Figure 3C, CagA-expressing MKN45 cells blocked etoposide-induced apoptosis from $17.62 \%$ of vector control to $11.00 \%, 5-\mathrm{FU}$-induced apoptosis from $18.77 \%$ of vector control to $6.48 \%$. However, the CagA- expressing MKN45 cells treated with cisplatin did not result in changes in the level of apoptosis in comparison with MKN45 vector control cells.

\section{Activation of Akt by CagA in gastric cancer cells}

To investigate the relationship of CagA expression and Akt activation in gastric cancer cells, we examined the p473-Akt level in AGS after transfection with various amount of $\mathrm{p} 3$ XFLAG vector or p3XFLAG-CagA plasmid $(0-4 \mu \mathrm{g})$. Total Akt levels were not influenced by the nature or amount of transfected DNA (Figure 4A, first panel). However, the phosphorylated Akt (p473-Akt) levels increased in response to CagA expression in a dose dependent manner (Figure 4A, second panel). The relative p473-Akt level was most evident after transfection with $4 \mu \mathrm{g}$ of CagA-expressing plasmid, up to three folds as compared with control (Figure 4A, graph).

To elucidate the role of activation of Akt in resistance to etoposide-induced apoptosis by CagA, AGS/ FLAG and AGS/FLAG-CagA cells were treated with etoposide for $30 \mathrm{~min}$ to $12 \mathrm{~h}$ to determine the effect of CagA on Akt activation in response to short- and longtime etoposide treatments. Consistent with previous results, activation of Akt was evident following etoposide treatment for $30 \mathrm{~min}$ in both AGS/FLAG and AGS/FLAGCagA cells (Figure 4B). While Akt activation decayed in AGS/FLAG cells, CagA maintained persistent p473-Akt expression after long-time etoposide treatment $(4 \mathrm{~h}$ and 12 h) (Figure 4B).

\section{Enhancement of etoposide cytotoxicity by PI- 3-kinase inhibitor LY294002 was attenuated in CagA-expressing gastric cancer cells}

To scrutinize whether CagA confers the resistance against chemotherapeutics via Akt activation, we examined the effect of PI-3-kinase inhibitors LY294002 on cell viability of AGS/FLAG and AGS/FLAG-CagA cells in the presence or absence of etoposide. The addition of LY294002 significantly enhanced cytotoxicity of etoposide in AGS/FLAG cells (Figure 5A), and to a lesser extent in the CagA-overexpressing AGS/FLAGCagA cells (Figure 5B). To confirm that the effect of LY294002 on etoposide-induced cytotoxicity were attributable to inhibition of Akt, AGS/FLAG-CagA cells transfected with dominant negative Akt (DNAkt) were assessed for cell viability after etoposide treatment. While AGS/FLAG-CagA cells had higher Akt activity (Figure 4A) and showed cytoprotection against etoposide-induced apoptosis, transfection of DN-Akt augmented etoposide-induced cytotoxicity (Figure 5C). This result further confirmed that Akt signaling pathway is selectively involved in etoposide-induced cytotoxicity in AGS cells. 


\section{DISCUSSION}

Adenocarcinoma of the stomach is the second most common cancer causing mortality in the world. Helicobacter pylori (H. pylori) is a well known carcinogen of gastric cancer. It has been shown that $H$. pylori strains expressing the cytotoxin-associated protein (CagA) associate high prevalence with gastric cancer as compared with CagA-negative strains [28]. CagA is secreted by $H$. pylori and translocated into gastric epithelial cells by type IV secretion system [18, 29]. CagA interacts with SHP-2 inducing a growth factor-like response in gastric epithelial cells [20]. Moreover, CagA, when co-expressed with HspB, induces cell proliferation in AGS gastric epithelial cells

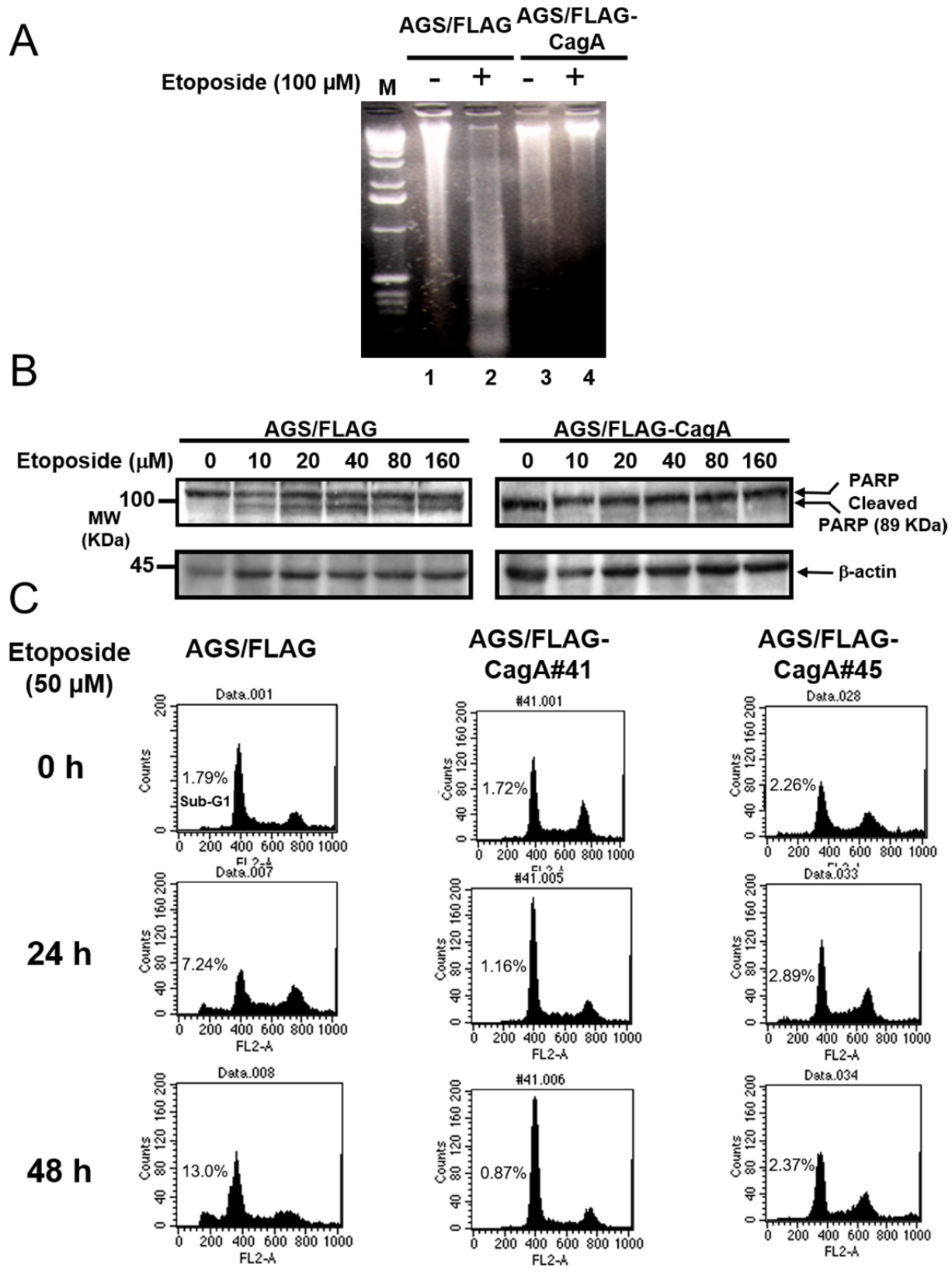

Figure 2: CagA expression resists etoposide-induced apoptosis. (A) DNA ladder formation assay. Control AGS cells untreated (lane 1) or treated with $100 \mu \mathrm{M}$ of etoposide (lane 2) and AGS/FLAG-CagA\#41 cells untreated (lane 3) or treated with $100 \mu \mathrm{M}$ of etoposide (lane 4 ) were subjected to $1.5 \%$ agarose gel electrophoresis, followed by staining with ethidium bromide.. Etoposide enhanced levels of DNA ladder formation in AGS cells (lane 2) but not in AGS/FLAG-CagA\#41 cells (lane 4). Representative data from one of two similar experiments are presented. (B) Serum-starved AGS/FLAG or AGS/FLAG-CagA\#41 cells were treated with etoposide at the concentrations indicated for $6 \mathrm{~h}$. The cell lysates $(50 \mu \mathrm{g})$ were analyzed for PARP and $\beta$-actin by Western blotting. Cleaved PARP, MW: 89 KDa. (C) Control and two stable CagA-expressing AGS cell lines (AGS/FLAG-CagA \#41, and \#45) were treated with $50 \mu$ M of etoposide for the time indicated. Apoptosis was quantitated by propidium iodide staining and flow cytometry. Representative histograms were shown to demonstrate the appearance of a sub- $\mathrm{G}_{1}$ peak in etoposide treated cells. 
[30]. As a result, CagA has been suggested as a potential bacterial oncoprotein in gastric carcinogenesis [31].

Etoposide binds to DNA and topoisomerase II, by which the drug induces apoptosis in AGS cells. Cag A activates Akt that suppresses apoptosis by phosphorylating, and therefore inhibiting, pro-apoptotic proteins, such as BAD [32], ASK1 [33] and caspase 9 [34]. Akt also suppresses apoptosis by promoting the degradation of $\mathrm{I} \kappa \mathrm{B}$, which leads to the activation of $\mathrm{NF}-\kappa \mathrm{B}[35]$ and to the suppression of apoptosis via the transcription of antiapoptotic genes, such as Bcl-2 [36], Bcl-XL [37], and IAP [38]. Akt may also directly stimulate DNA repair exerted

A
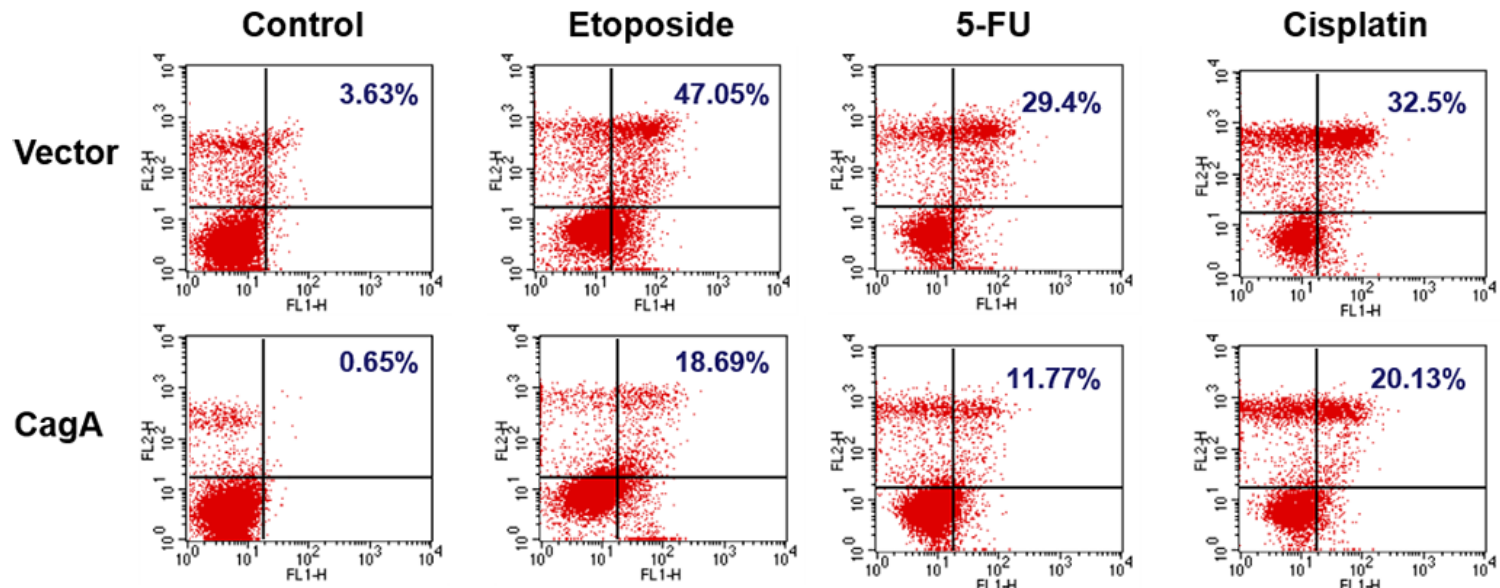

B

AGS
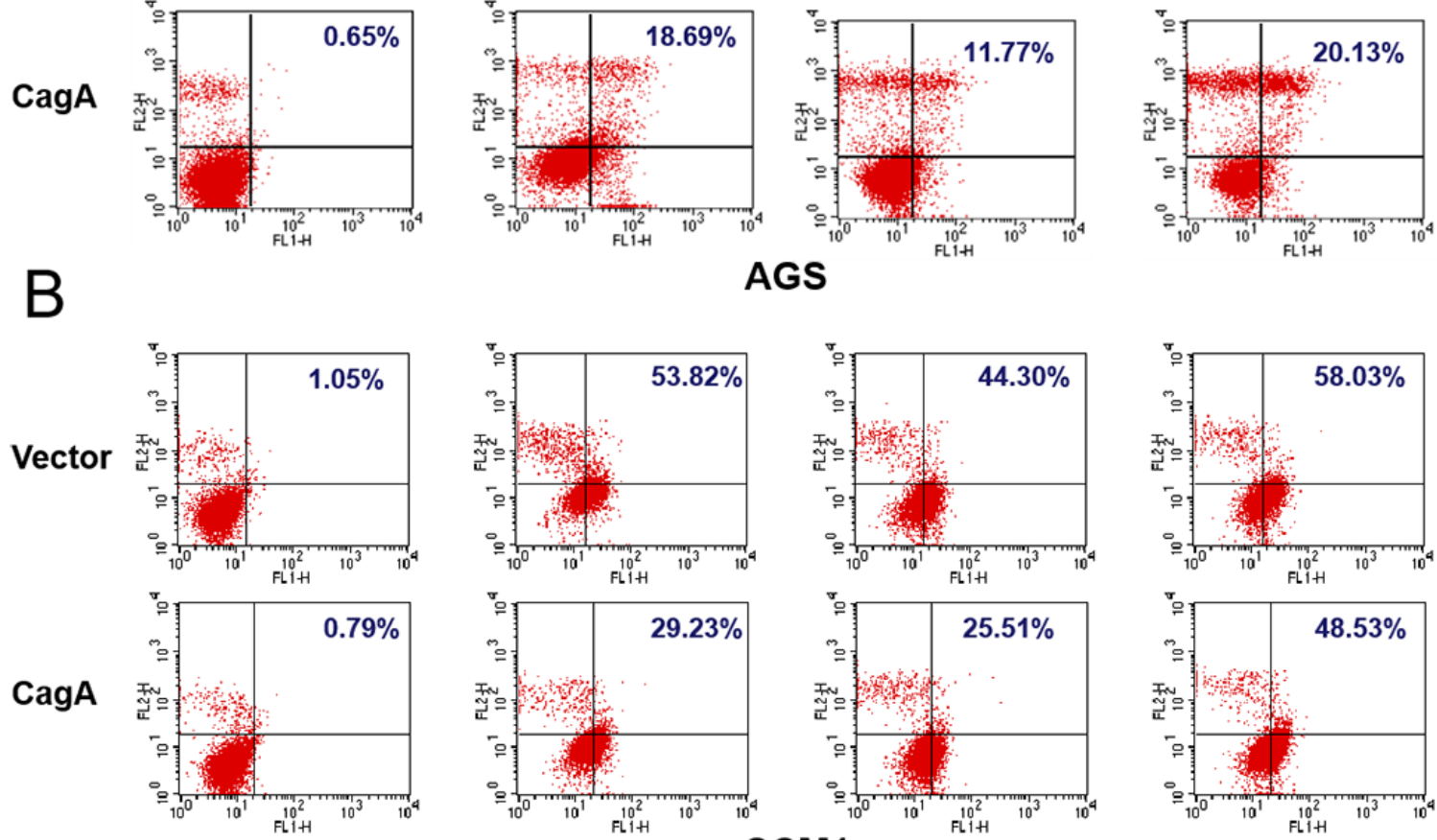

C
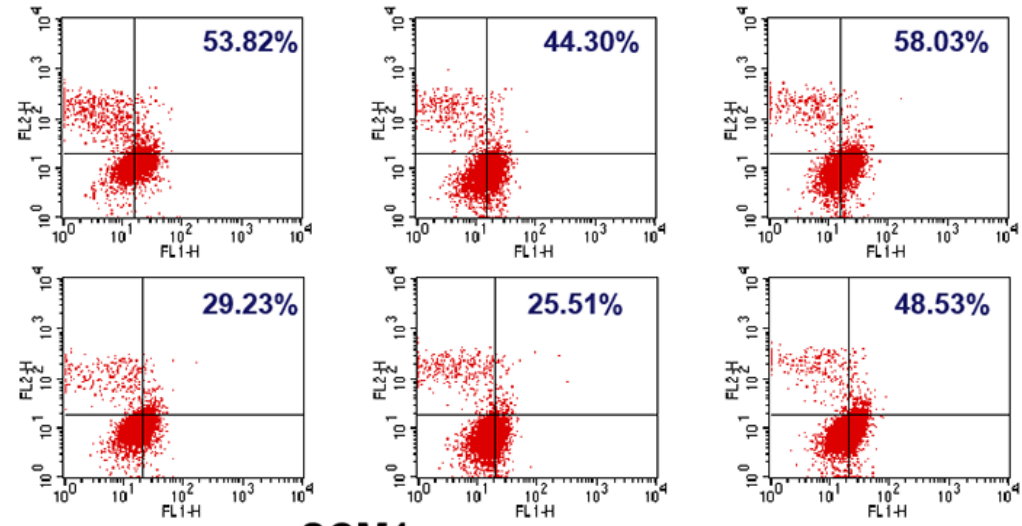

\section{SCM1}
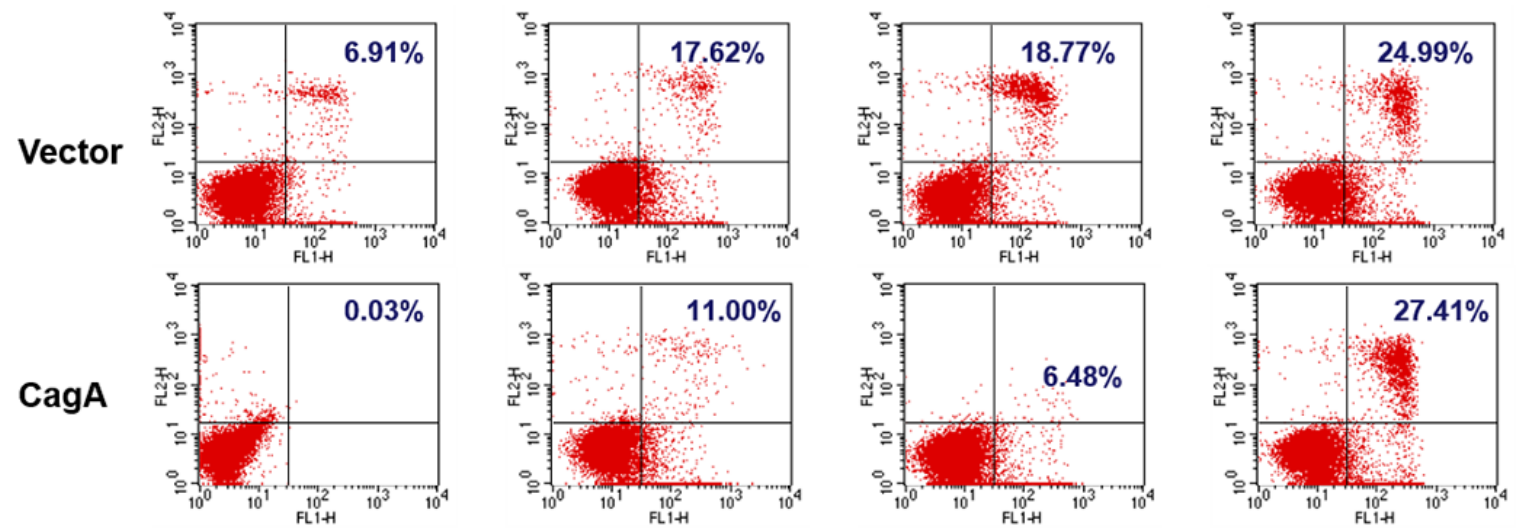

\section{MKN45}

Figure 3: CagA expression attenuates the cell death induced by chemotherapeutic drugs in three gastric cancer cell lines. Annexin V/ PI staining of gastric cancer cells, (A) AGS (B) SCM1 (C) MKN45, transfected with vector or CagA-expressing plasmids followed by treatment of three different chemotherapeutics, etoposide, cisplatin or 5-FU, at a concentration of $33 \mu \mathrm{M}$, for 24 hours. 
by etoposide. Following DNA damage, Akt binds to DNA$\mathrm{PK}$, phosphorylates it and regulates the accumulation of DNA-PK at damaged sites to assist DNA double strand break re-joining by non-homologous end joining (NHEJ) [39]. Akt signaling is activated in gastric cancer, which has been implicated in tumorigenesis of gastric cancer [40], influencing the chemoresistance of gastric cancers $[41,42]$, and correlating with the grade of malignancy in human gastric adenocarcinomas [43]. Besides, infection of CagA-positive $H$. pylori strains activates Akt in gastric epithelial cell lines, including AGS [44-47], MKN45 [45], MKN28 [45], and nontransformed epithelial cell line, MCF-10A [48], which attenuates cell apoptosis and promotes cell survival. Akt activation is a common observation in response to chemotherapy, including etoposide, suggesting an important role in inducing resistance to apoptosis in breast [26], small cell lung [49] and gastric cancer cells [24]. Our results showed that etoposide increased Akt phosphorylation as well as decreased cell viability through induction of apoptosis in AGS cells. However, this etoposide-induced apoptosis was much attenuated in CagA-expressing AGS gastric cancer cells, which may be attributable to further Akt activation by CagA expression.

We continued to test the chemoresistance extent conferred by CagA in AGS, and two additional gastric cancer cell lines, SCM1, and MKN45 treated with multiple chemotherapeutics including etoposide, 5-FU, or cisplatin (Figure 3). The results showed that in all three gastric cancer cell lines, CagA mediated cytoprotection
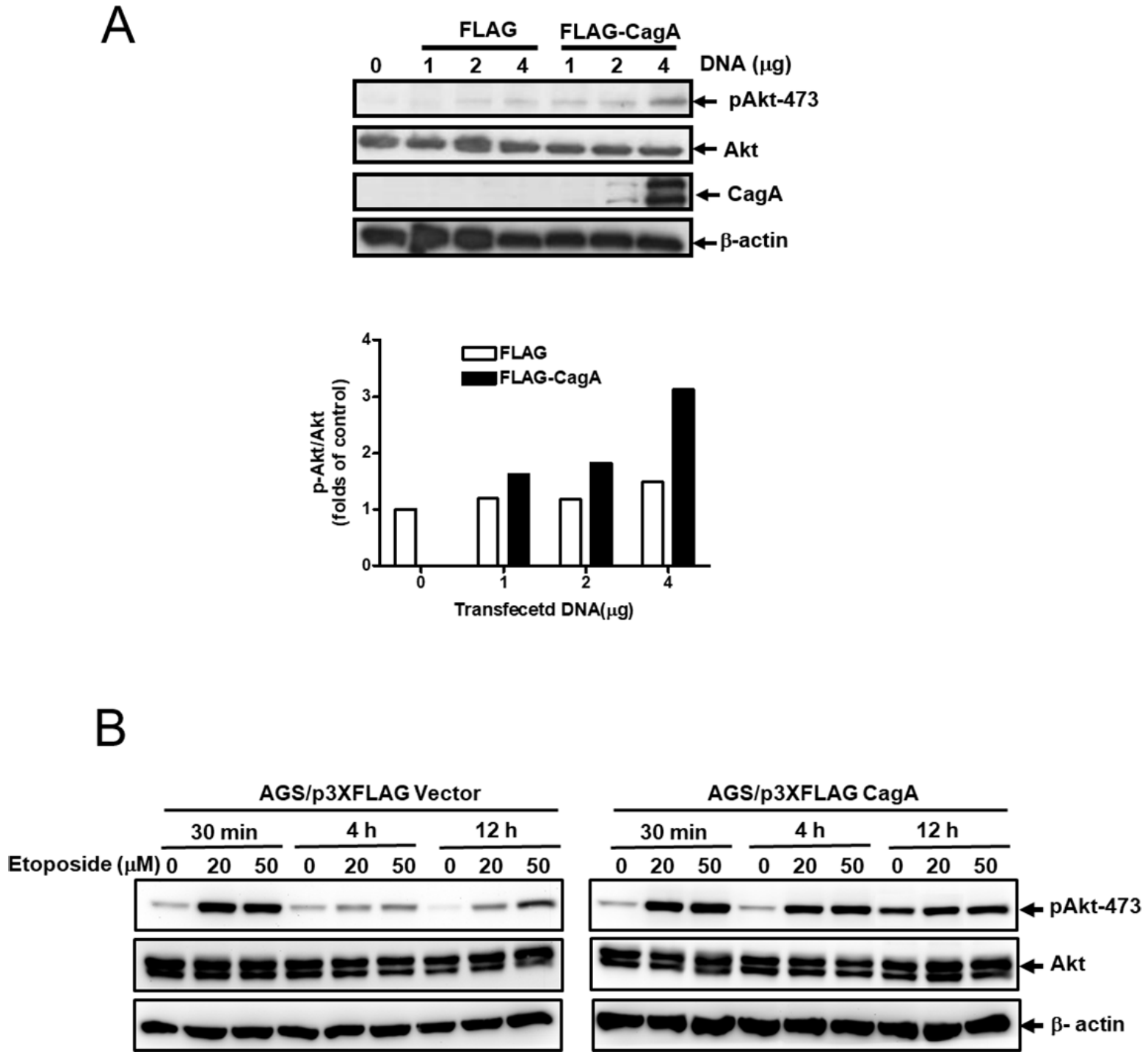

Figure 4: CagA expression activates Akt in gastric cancer cell. (A) AGS cells were transfected with p3XFLAG vector or p3XFLAG-CagA plasmid as indicated amounts. Cell lysates were analyzed by Western blot with anti-phospho-Akt (Ser 473), total Akt, CagA and $\beta$-actin antibodies. The relative expression levels of phospho-Akt (Ser 473) to total Akt were semi-quantified by Image $J$ software. (B) AGS/FLAG or AGS/FLAG-CagA stable cells were left untreated or treated with etoposide (20 or $50 \mu \mathrm{M})$ for $30 \mathrm{~min}$ to $12 \mathrm{~h}$, and cell lysates were analyzed by Western blot with anti-phospho-Akt (Ser 473), total Akt, and $\beta$-actin antibodies. The relative expression levels of phospho-Akt (Ser 473) to total Akt were semi-quantified by Image J software. 
against etoposide and 5-FU. CagA expression also exert some cytoprotection against cisplatin in AGS cells, but not in the other two gastric cancer cell lines (Figure 3, Cisplatin column). It is therefore intriguing to speculate that the extent of CagA-mediated chemoresistance may involve the interplay between the tumor cell factors and the action of the antitumor compounds.

Our data in Figure 4 corroborate the correlation of CagA expression and Akt activation. The phosphorylated Akt (P-Ser473-Akt) levels were increased with the

\section{A}

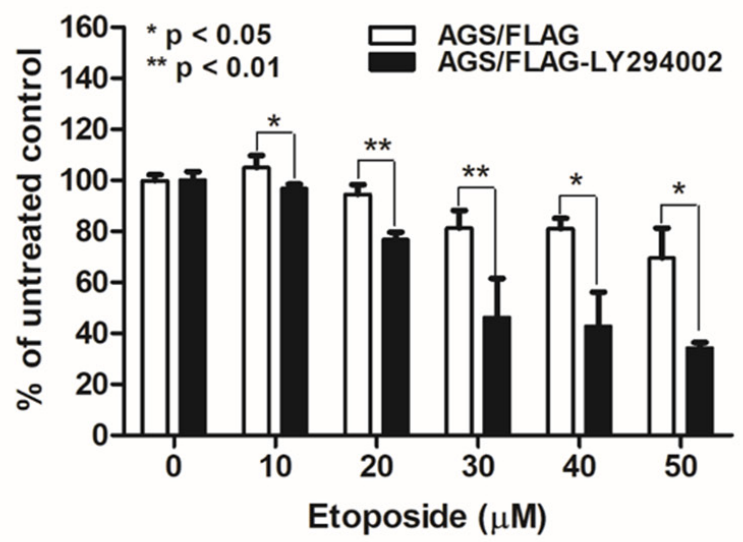

B
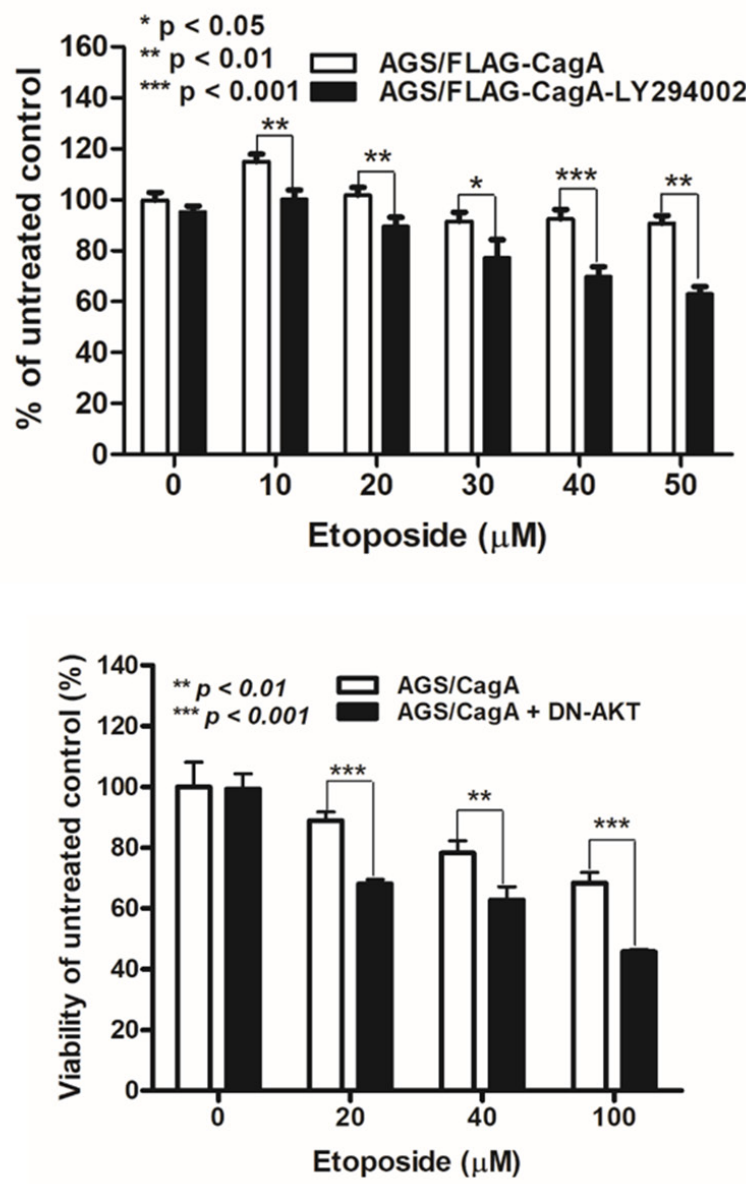

Figure 5: LY294002 and dominant-negative Akt mutant alter the sensitivity of CagA-expressing AGS cells to etoposide. (A) Control FLAG- or (B) FLAG-CagA-expressing stable AGS cells were plated at $5 \times 10^{4} /$ well and placed in serum-free medium for $24 \mathrm{~h}$ before being treated with etoposide at various concentrations $(0-50 \mu \mathrm{M})$ and LY294002 for $48 \mathrm{~h}$. MTT assay was performed to determine the cell viability. (C) AGS/FLAG-CagA stable cells were transiently transfected with DN-Akt, and cell viability in response to etoposide treatment was assessed by MTT assay. 
increasing amounts of transfected CagA DNA (Figure 4A). Interestingly, the enhanced Akt activation with increasing etoposide concentration is much more significant in the presence of CagA expression (Figure 4B). These results indicate that $\mathrm{CagA}$ mediated chemoresistance via Akt activation.

Administration of a potent PI3K inhibitor, LY294002 or transient transfection of a DN-Akt mutant inhibits Akt phosphorylation and greatly potentiates apoptosis caused by etoposide [24, 26]. In our study, etoposide-induced apoptosis was potentiated by LY294002 in control but to a lesser extent in CagA-expressing AGS cells, suggesting CagA may attenuate etoposide-mediated apoptosis via PI3K/Akt signaling pathway. To further elucidate the role of Akt in attenuation of etoposide-induced apoptosis by CagA, DN-Akt was transfected into CagA-expressing AGS cells followed by etoposide treatment. In agreement with our hypothesis, DN-Akt potentiated the etoposideinduced apoptosis even in CagA-expressing AGS cells, indicating that CagA suppresses etoposide-mediated apoptosis by Akt signaling pathway.

Many oncoproteins, survival factors, and growth factors have evolved various mechanisms for Akt activation. Given that Akt activation often correlates with cellular response to carcinogen [25], our data may have an important implication for cellular transformation induced by CagA-positive H. pylori. In light of the CagAinduced Akt activation, CagA may be a potential bacterial oncoprotein in gastric carcinogenesis. Furthermore, CagA potentiates Akt activation induced by etoposide by which it might lead to resistance of gastric cancer to standard chemotherapy. Therefore, it is plausible to determine the effect of CagA-positive H. pylori infection on treatment efficacy of chemotherapeutics in gastric cancer patients.

Taken together, this is the first study showing that CagA of $H$. pylori potentiates Akt activation and attenuates the etoposide-induced apoptosis in gastric cancer cells. CagA activates multiple anti-apoptotic signaling pathways of host cells, the PI3K/Akt activation of which is responsible for $H$. pylori-induced tumorigenesis of gastric cancer [40]. This CagA-dependent mechanism of etoposide resistance in gastric cancer cells may help develop state-of-the-art chemotherapeutic regimens. Since CagA activates oncogenic signaling pathway, pathological detection of CagA in gastric cancer surgical specimens may also have prognostic as well as therapeutic significance in clinical practices.

\section{MATERIALS AND METHODS}

\section{Cell lines and reagent}

Human gastric cancer cells, AGS (ATCC CRL1739) and SCM1 (ATCC CRL-5822), were obtained from American Type Culture Collection. MKN45 cell line (RCB1001) was obtained from RIKEN BioResource center. The cells were maintained in RPMI-1640 medium supplemented with $10 \%$ fetal calf serum, $50 \mu \mathrm{g} / \mathrm{ml}$ penicillin-streptomycin and $2 \mathrm{mM} \mathrm{L}$-glutamine at $37^{\circ} \mathrm{C}$ in a $5 \% \mathrm{CO}_{2}$ atmosphere. Etoposide, cisplatin, 5-Fluorouracil (5-FU), and LY294002 were purchased from Sigma (Saint Louis, Missouri, USA).

\section{Plasmids}

The full-length cagA gene was amplified from H. pylori strain 26695 by polymerase chain reaction (PCR) with specific primers containing unique KpnI sites (5'-GGGGTACCCACTAACGAAACTA TTGATCAAACAAG-3'; 5'-GGGGTACCCTTAAGAT TTTTGGAAACCACCTTTTG-3'). The PCR product was cloned into the KpnI site of the expression vector p3XFLAG-Myc-CMV ${ }^{\mathrm{TM}}$-26 (Sigma, Saint Louis, Missouri, USA) to generate p3XFLAG-CagA where upstream of full-length $\operatorname{cag} A$ gene is tagged with three adjacent FLAG epitopes (Asp-Tyr-Lys-Xaa-Xaa-Asp). Akt was tagged with HA (YPYDVPDYA) at its C-terminal end to generate Akt-HA (wt). Dominant-negative Akt (DN-Akt) was constructed by site-directed mutagenesis at the ATP binding site (K179M) from Akt-HA to express a kinase-dead Akt. All cloned plasmids were purified using Endofree plasmid kit (Qiagen, Hilden, Germany).

\section{Antibodies}

For Western blot analysis, rabbit polyclonal antibodies against phospho-Akt (Ser473, catalog no. 9271, 1:1,000 dilution) and nonphosphorylated total Akt (catalog no. 9272, 1:500 dilution) were purchased from Cell Signaling Technology (Beverly, MA). Anti-FLAG M2 and anti- $\beta$-actin antibodies were obtained from Sigma. Antibodies against poly(ADP-ribose) polymerase (PARP) were purchased from Santa Cruz Biotechnology, Inc. (Santa Cruz, CA).

\section{Stable CagA expression gastric cancer cell lines}

For selection of FLAG-CagA or FLAG stable transfectants, AGS, SCM1 and MKN45 cells were transfected with p3XFLAG-CagA or p3XFLAG vector plasmid and selected by resistance to G418 (Gibco-BRL) at the concentration of $400 \mu \mathrm{g} / \mathrm{mL}$. The protein expression was confirmed by Western blots.

\section{Immunoblot analysis}

AGS cells $\left(4 \times 10^{5}\right)$ were plated onto a 6-well tissue culture plate 24 hours before transfection with p3XFLAGCagA or p3XFLAG plasmid using FuGENE 6 transfection reagent (Boehringer Mannheim, Mannheim, Germany). After $48 \mathrm{~h}$, cells were suspended in $50 \mathrm{mmol} / \mathrm{L}$ Tris- $\mathrm{HCl}$ ( $\mathrm{pH}$ 7.4) buffer containing $1 \mathrm{mmol} / \mathrm{L}$ EGTA, $2 \mathrm{mmol} / \mathrm{L}$ dithiothreitol, $25 \mathrm{mmol} / \mathrm{L}$ sodium beta-glycerophosphate, $0.1 \mathrm{mmol} / \mathrm{L}$ phenylmethylsulfonyl fluoride, and $10 \mu \mathrm{g} / \mathrm{mL}$ 
aprotinin. An equal amount of protein extracts was fractionated by sodium dodecyl sulfate-polyacrylamide gel electrophoresis (SDS-PAGE) and transferred to a polyvinylidene difluoride membrane (Amersham Pharmacia Biotech, Buckinghamshire, England). The membrane was probed with anti-FLAG M2 antibodiy. AGS/ FLAG and AGS/FLAG-CagA stable cells were treated with varying concentrations of etoposide $(20$ or $50 \mu \mathrm{M})$ for $30 \mathrm{~min}$ to $12 \mathrm{~h}$, and the cell lysates were subjected to immunoblotting with anti-P-Ser473-Akt antibody followed by reprobing with anti-Akt or anti- $\beta$-actin antibodies.

\section{In vitro cell viability analysis}

The in vitro cell viability of the cell lines were assessed by MTT (3-[4,5-dimethylthiazol-2-yl]2,5diphenylterazolium bromide) assay. Control or stable CagA-expressing AGS cells $\left(5 \times 10^{4} /\right.$ well $)$ were plated in 96-well and treated with etoposide at various concentrations $(0-300 \mu \mathrm{M})$ for 24 to $48 \mathrm{~h}$. One hundred microliters of MTT reagent $(0.5 \mathrm{mg} / \mathrm{mL})$ was then added to each well. Cells were cultured for an additional $4 \mathrm{~h}$ and absorbance at $570 \mathrm{~nm}$ was measured.

\section{DNA fragmentation analysis}

Approximately $2 \times 10^{6}$ control or stable CagAexpressing AGS cells plated in $10 \mathrm{~cm}$-diameter dishes were untreated or treated with $100 \mu \mathrm{M}$ of etoposide for $48 \mathrm{~h}$. Cells were collected, and the cell pellets were mixed with $20 \mathrm{~mL}$ of lysis buffer (100 mM Tris-Cl, $20 \mathrm{mM}$ EDTA, $\mathrm{pH}$ $8.0,0.8 \% \mathrm{SDS})$. The lysate was then digested with $10 \mathrm{~mL}$ of RNase $(100 \mu \mathrm{g} / \mathrm{ml})$ at $37^{\circ} \mathrm{C}$ for $2 \mathrm{~h}$ and subsequently incubated with $10 \mathrm{~mL}$ of proteinase $\mathrm{K}(20 \mathrm{mg} / \mathrm{ml})$ at $50^{\circ} \mathrm{C}$ for $90 \mathrm{~min}$. After extraction with phenol and chloroform, the DNA was then precipitated with ethanol and dissolved in TE buffer. An equal amount of DNA from each sample was analyzed on a $1.5 \%$ agarose gel electrophoresis.

\section{Cleavage of PARP}

AGS/FLAG or AGS/FLAG-CagA\#41 cells were treated with serum starvation followed by etoposide treatment of various concentrations of etoposide $(0-160 \mu \mathrm{M})$ for $6 \mathrm{~h}$. The cell lysates $(50 \mu \mathrm{g})$ were analyzed for PARP and $\beta$-actin by Western blotting.

\section{Cell cycle assay}

Control (AGS/FLAG) or two stable CagA-expressing AGS cell lines (AGS/FLAG-CagA\#41 and AGS/FLAGCagA\#45) plated in $10 \mathrm{~cm}$-diameter dishes were treated with $50 \mu \mathrm{M}$ of etoposide for $0-48 \mathrm{~h}$. Etoposide-treated cells were trypsinized, washed with PBS and then fixed in $1 \mathrm{~mL} \mathrm{70 \%} \mathrm{ice-cold} \mathrm{methanol.} \mathrm{The} \mathrm{cells} \mathrm{were} \mathrm{resuspended}$ in $1 \mathrm{ml} 50 \mu \mathrm{g} / \mathrm{ml}$ propidium iodide staining solution containing $0.1 \%$ Triton X-100 and $2 \mathrm{mg} / \mathrm{ml}$ RNase A at room temperature for 1 hour in the dark. Subsequently, the nuclei were subjected to DNA fragmentation analysis in a FACScalibur (Becton Dickinson, San Jose, CA) and Cell Quest Pro software (Becton Dickinson, Mountain View, CA). Based on propidium iodide staining, nuclei in the sub- $\mathrm{G}_{1}$ marker window represent apoptotic cells.

\section{Annexin-V apoptosis assay}

Control or stable CagA-expressing AGS, SCM1 and MKN45 cells $\left(5 \times 10^{5} /\right.$ well $)$ were plated in 6 -well and treated with etoposide $(33 \mu \mathrm{M}), 5-\mathrm{FU}(33 \mu \mathrm{M})$ or Cisplatin $(33 \mu \mathrm{M})$ for $24 \mathrm{~h}$, trypsinized, and washed twice with PBS. Apoptosis was confirmed using an Annexin $\mathrm{V}$ Apoptosis Kit (BD Pharmingen) according to the manufacturer's instructions. Briefly, cells were washed 3 times with PBS; then, cells were analyzed immediately for apoptosis using Annexin V/PI staining. Washed cells were supplemented with $1 \%$ BSA and then stained directly with $10 \mu \mathrm{L}$ of PI and $2.5 \mu \mathrm{L}$ Annexin V-FITC after the addition of $222.5 \mu \mathrm{L}$ of binding buffer. Immediately after $10 \mathrm{~min}$ of incubation in the dark on ice, the cells were analyzed by flow cytometry. The percentage of positive cells was determined by using a FACSCalibur cytometer and Cell Quest Pro software.

\section{Transient transfections}

AGS/FLAG-CagA or AGS/FLAG cells $\left(1 \times 10^{5} /\right.$ well) plated in 12-well dishes were transfected with $2 \mu \mathrm{g}$ of DN-Akt-HA plasmid in triplicate using the FuGENE 6. After $24 \mathrm{~h}$, the cells were treated with increasing concentrations of etoposide for $24 \mathrm{~h}$. Cell viability was determined using MTT assay.

\section{Data analysis}

Data are given as mean \pm standard deviation of at least two independent experiments. Data fitting and statistical analyses were computed using the GraphPad Prism program version 5.0 (Graph Pad Software, San Diego, CA).

\section{ACKNOWLEDGMENTS AND FUNDING}

This research was partially supported by Taipei Veterans General Hospital grants VGH 93-B2-182, and VGH 94-B2-190 (K.H. Lan).

\section{CONFLICTS OF INTEREST}

None.

\section{REFERENCES}

1. Graham DY, Lew GM, Klein PD, Evans DG, Evans DJ Jr, Saeed ZA, Malaty HM. Effect of treatment of Helicobacter 
pylori infection on the long-term recurrence of gastric or duodenal ulcer. A randomized, controlled study. Ann Intern Med. 1992; 116:705-8.

2. Crabtree JE, Wyatt JI, Trejdosiewicz LK, Peichl P, Nichols PH, Ramsay N, Primrose JN, Lindley IJ. Interleukin-8 expression in Helicobacter pylori infected, normal, and neoplastic gastroduodenal mucosa. J Clin Pathol. 1994; 47:61-6.

3. Fan XG, Kelleher D, Fan XJ, Xia HX, Keeling PW. Helicobacter pylori increases proliferation of gastric epithelial cells. Gut. 1996; 38:19-22.

4. Moss SF, Calam J, Agarwal B, Wang S, Holt PR. Induction of gastric epithelial apoptosis by Helicobacter pylori. Gut. 1996; 38:498-501.

5. Peek RM Jr, Moss SF, Tham KT, Perez-Perez GI, Wang S, Miller GG, Atherton JC, Holt PR, Blaser MJ. Helicobacter pylori cagA + strains and dissociation of gastric epithelial cell proliferation from apoptosis. J Natl Cancer Inst. 1997; 89:863-8.

6. Xia HH, Talley NJ. Apoptosis in gastric epithelium induced by Helicobacter pylori infection: implications in gastric carcinogenesis. Am J Gastroenterol. 2001; 96:16-26.

7. Forman D, Webb P, Parsonnet J. H pylori and gastric cancer. Lancet. 1994; 343:243-4.

8. Eslick GD, Lim LL, Byles JE, Xia HH, Talley NJ. Association of Helicobacter pylori infection with gastric carcinoma: a meta-analysis. Am J Gastroenterol. 1999; 94:2373-9.

9. Honda S, Fujioka T, Tokieda M, Satoh R, Nishizono A, Nasu M. Development of Helicobacter pylori-induced gastric carcinoma in Mongolian gerbils. Cancer Res. 1998; 58:4255-9.

10. Ogura K, Maeda S, Nakao M, Watanabe T, Tada M, Kyutoku T, Yoshida H, Shiratori Y, Omata M. Virulence factors of Helicobacter pylori responsible for gastric diseases in Mongolian gerbil. J Exp Med. 2000; 192:1601-10.

11. Watanabe $T$, Tada M, Nagai H, Sasaki S, Nakao M. Helicobacter pylori infection induces gastric cancer in mongolian gerbils. Gastroenterology. 1998; 115:642-8.

12. Censini S, Lange C, Xiang Z, Crabtree JE, Ghiara P, Borodovsky M, Rappuoli R, Covacci A. cag, a pathogenicity island of Helicobacter pylori, encodes type I-specific and disease-associated virulence factors. Proc Natl Acad Sci U S A. 1996; 93:14648-53.

13. Sharma SA, Tummuru MK, Miller GG, Blaser MJ. Interleukin-8 response of gastric epithelial cell lines to Helicobacter pylori stimulation in vitro. Infect Immun. 1995; 63:1681-87.

14. Graham DY, Yamaoka Y. H. pylori and cagA: relationships with gastric cancer, duodenal ulcer, and reflux esophagitis and its complications. Helicobacter. 1998; 3:145-51.

15. Asahi M, Azuma $T$, Ito $S$, Ito $Y$, Suto $H$, Nagai $Y$, Tsubokawa M, Tohyama Y, Maeda S, Omata M, Suzuki T, Sasakawa C. Helicobacter pylori CagA protein can be tyrosine phosphorylated in gastric epithelial cells. J Exp Med. 2000; 191:593-602.

16. Segal ED, Cha J, Lo J, Falkow S, Tompkins LS. Altered states: Involvement of phosphorylated CagA in the induction of host cellular growth changes by Helicobacter pylori. PNAS. 1999; 96:14559-64.

17. Selbach M, Moese S, Hauck CR, Meyer TF, Backert S. Src Is the Kinase of the Helicobacter pylori CagA Protein in Vitro and in Vivo. J Biol Chem. 2002; 277:6775-8.

18. Stein M, Rappuoli R, Covacci A. Tyrosine phosphorylation of the Helicobacter pylori CagA antigen after cag-driven host cell translocation. Proc Natl Acad Sci U S A. 2000; 97:1263-8.

19. Higashi H, Tsutsumi R, Muto S, Sugiyama T, Azuma T, Asaka M, Hatakeyama M. SHP-2 tyrosine phosphatase as an intracellular target of Helicobacter pylori CagA protein. Science. 2002; 295:683-6.

20. Webb PM, Crabtree JE, Forman D, and The Eurogst Study Group. Gastric cancer, cytotoxin-associated gene A-positive Helicobacter pylori, and serum pepsinogens: an international study. Gastroenterology. 1999; 116:269-76.

21. Hande KR. Etoposide: four decades of development of a topoisomerase II inhibitor. Eur J Cancer. 1998; 34:1514-21.

22. Belani CP, Doyle LA, Aisner J. Etoposide: current status and future perspectives in the management of malignant neoplasms. Cancer Chemother Pharmacol. 1994; 34:S118-26.

23. Tang D, Okada H, Ruland J, Liu L, Stambolic V, Mak TW, Ingram AJ. Akt is activated in response to an apoptotic signal. J Biol Chem. 2001; 276:30461-6.

24. Liu SQ, Yu JP, Yu HG, Lv P, Chen HL. Activation of Akt and ERK signalling pathways induced by etoposide confer chemoresistance in gastric cancer cells. Dig Liver Dis. 2006; 38:310-8.

25. West KA, Castillo SS, Dennis PA. Activation of the PI3K/ Akt pathway and chemotherapeutic resistance. Drug Resist Updat. 2002; 5:234-48.

26. Clark AS, West K, Streicher S, Dennis PA. Constitutive and inducible Akt activity promotes resistance to chemotherapy, trastuzumab, or tamoxifen in breast cancer cells. Mol Cancer Ther. 2002; 1:707-17.

27. Gagnaire A, Nadel B, Raoult D, Neefjes J, Gorvel JP. Collateral damage: insights into bacterial mechanisms that predispose host cells to cancer. Nat Rev Microbiol. 2017; 15:109-28.

28. Huang JQ, Zheng GF, Sumanac K, Irvine EJ, Hunt RH. Meta-analysis of the relationship between cagA seropositivity and gastric cancer. Gastroenterology. 2003; 125:1636-44.

29. Odenbreit S, Puls J, Sedlmaier B, Gerland E, Fischer W, Haas R. Translocation of Helicobacter pylori CagA into gastric epithelial cells by type IV secretion. Science. 2000; 287:1497-500.

30. De Luca A, Baldi A, Russo P, Todisco A, Altucci L, Giardullo N, Pasquale L, Iaquinto S, D'Onofrio V, 
Parodi MC, Paggi MG, Iaquinto G. Coexpression of Helicobacter pylori's proteins CagA and HspB induces cell proliferation in AGS gastric epithelial cells, independently from the bacterial infection. Cancer Res. 2003; 63:6350-6.

31. Hatakeyama M. Helicobacter pylori CagA as a potential bacterial oncoprotein in gastric carcinogenesis. Pathol Biol (Paris). 2003; 51:393-4.

32. Datta SR, Dudek H, Tao X, Masters S, Fu H, Gotoh Y, Greenberg ME. Akt phosphorylation of BAD couples survival signals to the cell-intrinsic death machinery. Cell. 1997; 91:231-41.

33. Kim AH, Khursigara G, Sun X, Franke TF, Chao MV. Akt phosphorylates and negatively regulates apoptosis signalregulating kinase 1. Mol Cell Biol. 2001; 21:893-901.

34. Cardone MH, Roy N, Stennicke HR, Salvesen GS, Franke TF, Stanbridge E, Frisch S, Reed JC. Regulation of cell death protease caspase-9 by phosphorylation. Science. 1998; 282:1318-21.

35. Ozes ON, Mayo LD, Gustin JA, Pfeffer SR, Pfeffer LM, Donner DB. NF-kappaB activation by tumour necrosis factor requires the Akt serine-threonine kinase. Nature. 1999; 401:82-5.

36. Catz SD, Johnson JL. Transcriptional regulation of bcl-2 by nuclear factor kappa B and its significance in prostate cancer. Oncogene. 2001; 20:7342-51.

37. Chen C, Edelstein LC, Gelinas C. The Rel/NF-kappaB family directly activates expression of the apoptosis inhibitor Bcl-x(L). Mol Cell Biol. 2000; 20:2687-95.

38. You M, Ku PT, Hrdlickova R, Bose HR Jr. ch-IAP1, a member of the inhibitor-of-apoptosis protein family, is a mediator of the antiapoptotic activity of the v-Rel oncoprotein. Mol Cell Biol. 1997; 17:7328-41.

39. Roos WP, Thomas AD, Kaina B. DNA damage and the balance between survival and death in cancer biology. Nat Rev Cancer. 2016; 16:20-33.

40. Yong X, Tang B, Li BS, Xie R, Hu CJ, Luo G, Qin Y, Dong H, Yang SM. Helicobacter pylori virulence factor CagA promotes tumorigenesis of gastric cancer via multiple signaling pathways. Cell Commun Signal. 2015; 13: 30.

41. Ang KL, Shi DL, Keong WW, Epstein RJ. Upregulated Akt signaling adjacent to gastric cancers: implications for screening and chemoprevention. Cancer Lett. 2005; 225:53-9.
42. Oki E, Baba H, Tokunaga E, Nakamura T, Ueda N, Futatsugi M, Mashino K, Yamamoto M, Ikebe M, Kakeji Y, Maehara Y. Akt phosphorylation associates with LOH of PTEN and leads to chemoresistance for gastric cancer. Int $\mathrm{J}$ Cancer. 2005; 117:376-80.

43. Kobayashi I, Semba S, Matsuda Y, Kuroda Y, Yokozaki H. Significance of Akt phosphorylation on tumor growth and vascular endothelial growth factor expression in human gastric carcinoma. Pathobiology. 2006; 73:8-17.

44. Nagy TA, Frey MR, Yan F, Israel DA, Polk DB, Peek RM Jr. Helicobacter pylori regulates cellular migration and apoptosis by activation of phosphatidylinositol 3-kinase signaling. J Infect Dis. 2009; 199:641-51.

45. Tabassam FH, Graham DY, Yamaoka Y. Helicobacter pylori activate epidermal growth factor receptor- and phosphatidylinositol 3-OH kinase-dependent Akt and glycogen synthase kinase 3beta phosphorylation. Cell Microbiol. 2009; 11:70-82.

46. Yoon JH, Seo HS, Choi SS, Chae HS, Choi WS, Kim O, Ashktorab H, Smoot DT, Nam SW, Lee JY, Park WS. Gastrokine 1 inhibits the carcinogenic potentials of Helicobacter pylori CagA. Carcinogenesis. 2014; 35:2619-29.

47. Suzuki M, Mimuro H, Kiga K, Fukumatsu M, Ishijima N, Morikawa H, Nagai S, Koyasu S, Gilman RH, Kersulyte D, Berg DE, Sasakawa C. Helicobacter pylori CagA phosphorylation-independent function in epithelial proliferation and inflammation. Cell Host Microbe. 2009; 5:23-34.

48. Vallejo-Flores G, Torres J, Sandoval-Montes C, ArevaloRomero H, Meza I, Camorlinga-Ponce M, Torres-Morales J, Chavez-Rueda AK, Legorreta-Haquet MV, Fuentes-Panana EM. Helicobacter pylori CagA Suppresses Apoptosis through Activation of AKT in a Nontransformed Epithelial Cell Model of Glandular Acini Formation. Biomed Res Int. 2015; 2015: 761501.

49. Kraus AC, Ferber I, Bachmann SO, Specht H, Wimmel A, Gross MW, Schlegel J, Suske G, Schuermann M. In vitro chemo- and radio-resistance in small cell lung cancer correlates with cell adhesion and constitutive activation of AKT and MAP kinase pathways. Oncogene. 2002; 21:8683-95. 